\title{
Boundaries within boundaries: Identifying the boundaries facing private firms that are in financial distress
}

\begin{tabular}{|c|c|}
\hline \multicolumn{2}{|c|}{$\begin{array}{l}\text { Authors: } \\
\text { Keith J. Fairhurst }{ }^{1} \text { ( } \\
\text { Marius Pretorius }\end{array}$} \\
\hline \multicolumn{2}{|c|}{$\begin{array}{l}\text { Affiliations: } \\
{ }^{1} \text { Department of Business } \\
\text { Management, University of } \\
\text { Pretoria, South Africa }\end{array}$} \\
\hline \multicolumn{2}{|c|}{$\begin{array}{l}\text { Corresponding author: } \\
\text { Keith Fairhurst, } \\
\text { keith@unleashconsult.com }\end{array}$} \\
\hline \multicolumn{2}{|c|}{$\begin{array}{l}\text { Dates: } \\
\text { Received: } 28 \text { July } 2017 \\
\text { Accepted: } 09 \text { Oct. } 2018 \\
\text { Published: } 21 \text { Feb. } 2019\end{array}$} \\
\hline \multicolumn{2}{|c|}{$\begin{array}{l}\text { How to cite this article: } \\
\text { Fairhurst, K.J. \& Pretorius, M. } \\
2019 \text {, 'Boundaries within } \\
\text { boundaries: Identifying the } \\
\text { boundaries facing private } \\
\text { firms that are in financial } \\
\text { distress', Southern African } \\
\text { Journal of Entrepreneurship } \\
\text { and Small Business } \\
\text { Management 11(1), a147. } \\
\text { https://doi.org/10.4102/ } \\
\text { sajesbm.v11i1.147 }\end{array}$} \\
\hline \multicolumn{2}{|c|}{$\begin{array}{l}\text { Copyright: } \\
\text { (c) 2019. The Authors } \\
\text { Licensee: AOSIS. This } \\
\text { is licensed under the } \\
\text { Creative Commons } \\
\text { Attribution License. }\end{array}$} \\
\hline \multicolumn{2}{|l|}{ Read online: } \\
\hline 回神回 & $\begin{array}{l}\text { Scan this QR } \\
\text { code with your } \\
\text { smart phone or } \\
\text { mobile device } \\
\text { to read online. }\end{array}$ \\
\hline
\end{tabular}

Background: Delay in cognition by management is likely to see a firm's distress worsening and the turnaround potential of a firm eroded. This inertia and resistance to change are further likely to result in antecedents absent in the required cognition of distress to trigger turnaround actions.

Aim: To explore firstly the Zone of Insolvency (ZOI), and the boundary of financial distress, secondly, agency theory, boards, directors and the ZOI and finally, how these constructs may influence cognition of distress and the firm turnaround boundary value.

Setting: The sample studied was drawn from the population of all privately owned firms that had filed for Business Rescue in South Africa between 01 May 2011 and 30 June 2016.

Methods: A quantitative research approach consistent with an objective position was utilised. The approach included descriptive statistical analysis and the measurement of strength of relationship between variables.

Results: We identified two boundaries that exist as triggers in respect of the required turnaround action: firstly, the boundary of the zone of insolvency (ZOI), and secondly, the turnaround boundary that occurs at some time after the onset of distress and once management has recognised and accepted the distressed position. The period between the two boundaries is a period that may see the turnaround potential of the distressed firm further eroded even beyond the point of no return, making a turnaround impossible.

Conclusion: Quantification of the difference in value of the firm between the onset of financial distress and evidence of direct action to turn around the distressed firm may be termed 'the cost of cognition delay'. Understanding the cost of cognition delay contributes to practice and academic interests and for firms that rely on the legal protection of formal turnaround processes, it may be argued that the act of formal filing is a signal that cognition has occurred.

\section{Introduction}

Arresting decline and preventing financial distress of a firm are dependent on the crucial first step of management, recognising and admitting that the firm is distressed (Gopinath 1991). Arguments put forward by Schulze, Lubatkin and Dino (2003) may provide two reasons as to why this does not happen. Firstly, they suggest that based on agency theory, owners with a controlling interest define the value of the firm that they control in terms of personal utility, which may translate to their making choices in favour of their personal wealth and not necessarily in the interests of the firm (Schulze et al. 2003). Secondly, they agree with the view that the equity owned by management and the board influences the board's thinking and decisions (Morck, Shleifer \& Vishny 1988; Schulze et al. 2003).

Other scholars have recognised that the structure and composition of boards have an influence on the incidence of financial distress (Ayotte, Hotchkiss \& Thorburn 2013; Elloumi \& Gueyié 2001). In addition, the role performed by boards and directors is recognised as the principal mechanism for corporate governance (Cadbury 2000), and a key consideration during times of financial distress is the shifting fiduciary duty of the board (Ayotte et al. 2013). Furthermore, it is increasingly argued that, because of their impact on decisions and view on risk, corporate governance mechanisms have a significant influence on the probability of financial distress of a firm (Djerbi \& Anis 2015; Manzaneque, Priego \& Merino 2015).

The contemplation of financial distress routinely uses the idea of a boundary as a way of predicting default on debt obligations. The most common measure of a boundary in this respect is where the 
zero net worth boundary equals the face value of debt (Davydenko 2012). Davydenko describes this as the point at which the market value of a firm's assets falls below the face value of debt. This description matches the conventional calculation (total assets less total liabilities) (Republic of South Africa [RSA] Companies Act 71 of 2008) (RSA 2008) (with effect from 01 May 2011, Ch. 4 (1) (a)) of a firm's solvency.

Davydenko also noted that 'the majority of economically insolvent firms do not default for at least one year' and pointed out an alternative view to the value-based boundary assumption, arguing that a firm defaults when its cash flow cannot meet the demands of its debt obligations. As an extension to this view, it may be argued that the default boundary is likely to locate beyond the zone of insolvency (ZOI) boundary but may not coincide with a boundary that may be termed 'the turnaround boundary'.

To explore these boundaries, various variables are considered. Firstly, this article explores the ZOI and the boundary of financial distress; secondly, agency theory, boards, directors and the ZOI; and finally, how these constructs may influence cognition of distress and the firm turnaround boundary value.

\section{Zone of insolvency}

The ZOI provides context for an appreciation of the interaction between corporate failure, financial distress and turnaround of any firm. It is an eloquent term for the period of financial distress that may not be generally evident, but exists prior to actual filing for insolvency, bankruptcy or business rescue (e.g. Chapter 6 in South Africa or Chapter 11 in the United States) (Barondes et al. 2007; Rajak 2008; Tung 2006). Although the legal principles stem from as far back as Salomon us Salomon \& Co Ltd - a landmark United Kingdom (UK) company law case in 1897 (Rajak 2008), the term first emerged in the Credit Lyonaisse vs Pathe Communications case in respect of which a decision was handed down by the Court of Chancery of Delaware on 30 December 1991 (Allen 1992).

It has been reasonably argued that the ZOI is an imprecise construct and difficult to determine (Barondes et al. 2007). Simply put by Barondes et al. (2007), it occurs when:

... it [the company] cannot generate and/or obtain enough cash to pay for its projected obligations and fund its business requirements for working capital and capital expenditures with a reasonable cushion to cover the variability of its business needs over time. (p. 235)

The argument posits that even if a company is not legally insolvent or bankrupt, as it nears the point of bankruptcy and by continuing to operate in a ZOI during which shareholders are 'out of the money', creditors may be viewed as the rightful recipients of any residual value derived from corporate actions. In the South African new Companies Act (Companies Act 71 of 2008, 2011) (RSA 2008), a definition for 'financial distress' is provided in Chapter 6, Section 128 (1) (f) as 'in reference to a particular company at any particular time, means that':
- it appears to be reasonably unlikely that the company will be able to pay all of its debts as they fall due and payable within the immediately ensuing 6 months; or

- it appears to be reasonably likely that the company will become insolvent within the immediately ensuing 6 months (S 128 [1] [f]).

This study uses the 'zone of insolvency' construct as the context for understanding antecedent board attributes and equity ownership patterns of distressed businesses. It also uses the Ch. 6 Sect 128 (1) (f) (RSA 2008) definition of financial distress as the mechanism for 'determining the initiation of the zone of insolvency'.

\section{Zone of insolvency - decision-making}

It is argued that discretion of management in the ZOI is reduced as a consequence of closer scrutiny by boards, and the reduced or total withdrawal of cooperation from creditors, banks, bondholders and suppliers of goods and services (Trahms, Ndofor \& Sirmon 2013). The result is a narrowing range of options and, consequently, decisions have to be made against the backdrop of an increasing prospect of failure and loss.

\section{Zone of insolvency - deepening insolvency}

Behavioural economic theory states that decision-makers attempting to deal with challenges, when faced with the prospect of loss, may be drawn to high-risk options with the hope that the outcome will alleviate the distressed position. This behaviour has been explained by research on decisionmaking under circumstances of risk which shows that people are inclined to be risk averse in the face of sure gains but are inclined to become risk seeking in the face of sure losses (Kahneman \& Tversky 1979). Therefore, it is reasonable to postulate that as financial distress increases, and the prospect of sure losses also increases, so the level of risk-seeking behaviour of management also increases (Wiseman \& GomezMejia 1998), particularly in distressed businesses where the shareholders, management and executive directors are the same people (i.e. an 'agency relationship' does not exist).

It also follows that, without any balancing influences, such as capable independent directors, management may take riskier decisions and may hold out for far too long before taking decisive action. This is likely to lead to deepening insolvency at the very least or bankruptcy and liquidation.

For the purposes of this study, an appreciation of the 'zone of insolvency' is important because, firstly, for companies in the 'zone of insolvency' it is argued that the fiduciary duties of directors expand to include creditors as they may be considered the rightful residual claimants at that point. Secondly, in privately owned companies, where shareholders and management are often the same people, an agency relationship may not exist. Thus, the key driver for sound corporate governance principles may be absent and result in a lack of suitable independent oversight and controls. 
Finally when faced with the prospect of loss, management may be inclined to be unreasonably risk seeking at the expense of creditors and other financiers.

\section{Agency theory across the boundary of financial distress}

The theory of the firm is fundamental to the study of agency theory with Jensen and Meckling's (1976) definition, having become most recognised:

It is a legal fiction which serves as a focus for a complex process in which the conflicting objectives of individuals (some of whom may 'represent' other organizations) are brought into equilibrium within a framework of contractual relations. (p. 9)

The terms 'conflicting objectives of individuals' and 'equilibrium' are particularly significant as it may be argued that contracts that bring about equilibrium are created while a firm is financially healthy. It therefore follows that as a firm approaches the ZOI and equilibrium is disturbed, (1) some of the contractual terms such as payment of debt may not be possible and (2) the conflicting objectives of individuals may lead to a lack of willingness on the part of some actors to meet other contractual obligations. The inherent tension present in relationships where separation of ownership and management exists was noted as early as 1776 when Smith (1776) said:

... managers rather of other people's money than of their own, it cannot well be expected, that they should watch over it with the same anxious vigilance with which the partners in a private copartnery frequently watch over their own. (p. 606)

What Smith does not specify, but is equally true, is that the managers may also expropriate value for themselves that should in the normal course of events accrue to the owners. Such lost value and the costs of limiting the loss of value are collectively known as 'agency cost', which is defined by Jensen and Meckling (1976) as the sum of the monitoring expenditures by the principal, the bonding expenditures by the agent and the residual loss.

Monitoring expenditures are logically the costs incurred by the owners to monitor the choices and behaviour of managers but are not limited to monitoring activities and include activities aimed at control. These costs could include the costs of maintaining a board of directors, conducting independent audits and any other review mechanism.

In respect of bonding expenditures, Jensen and Meckling (1976) observe that:

... it will pay the agent to expend resources [bonding expenditures] to guarantee that he will not take certain actions which would harm the principal or to ensure that the principal will be compensated if he does take such actions. (p. 5)

In practice, specific circumstances will determine the nature of bonding costs, but a useful example is that of Directors' and Officers' (D\&O) insurance.
Residual loss includes all other leakage that occurs from the firm as a result of the agency relationship, but otherwise could accrue as value to the firm's owner. This leakage can be pecuniary or non-pecuniary in nature and may even take the form of opportunity costs.

Many examples can be advanced in respect of opportunity costs, but a common definition of 'opportunity cost' is 'that which is given up in order to get something else' (Polley 2015:13). An example of an opportunity cost to shareholders would be the case of management choosing not to embark on a particular project because of the personal risk to their career or the personal inconvenience that they may have to bear. Identifying opportunity costs would be a matter of judgement and would vary from case to case.

Jensen and Meckling (1976) go on to describe how the sources of capital of a firm influence the scale of agency costs. They describe the situation where all the capital of the firm is provided by the owner or manager, and argue that the agency costs will be zero as no agency relationship exists. They then demonstrate, as illustrated in Figure 1, that the greater the amount of external capital - whether debt or equity provided to a firm, the greater the total agency cost.

The view that agency cost increases as the amount of external financing increases, irrespective of whether it is debt or equity, is logical and seems reasonable. In a perfect world, it could be argued that the residual costs should be zero if optimal monitoring (including control) and bonding activities were in place.

The activities that give rise to the monitoring and bonding costs may be seen as governance mechanisms. The creation of governance mechanisms is one of the outcomes of researching agency theory and attempting to solve the agency problem (Eisenhardt 1989). This seems to be supported by the work of Ang, Cole and Lin (2000), who found that agency costs are (1) higher when a firm is managed by an outsider (non-shareholder), (2) become lower as the amount of

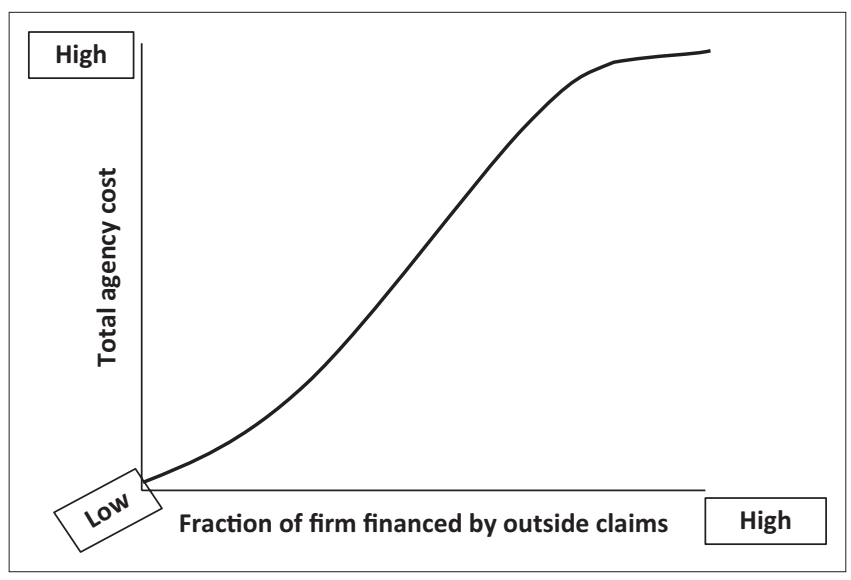

Source: Adapted from Jensen, M.C. \& Meckling, W., 1976, 'Theory of the firm: Managerial behaviour, agency costs and ownership structure', Journal of Financial Economics 3, 59 https://doi.org/10.1016/0304-405x(76)90026-x

FIGURE 1: Total agency cost increases as the amount of external financing increases. 
shareholding owned by management increases, (3) increase as the number of shareholders who are not managers grows and (4) tend to be lower when there is greater monitoring in place by banks (Ang et al. 2000).

The first three findings of Ang et al. (2000) can be aligned to the view that the value of a firm managed by a controlling owner(s) is equal to the owner(s)' view of the personal utility that the firm provides (Schulze et al. 2003). It follows that the greater proportion of shareholding owned by management, the less governance activity is desired because the conditions for an agency relationship are reduced and there is a great incentive by shareholders to maximise personal utility. From Ang et al.'s findings one may speculate that when a firm's funding is predominantly external debt, then the providers (normally banks) will put in place their own monitoring mechanisms. This protection is normally achieved through explicit contracts that include covenants that require specific action from management when significant change takes place. It may, however, be argued that under particular circumstances, for instance, should the firm enter the ZOI, then the debt funders may become the principal in a form of agency relationship.

A conventional agency theory assumption is that separation of ownership and control exists. However, where a high proportion of equity is owned by management, this is unlikely to be the case. This situation, when coupled with a strong incentive for personal utility maximisation on the part of owners, could result in the objectives of owners and the objectives of funders being potentially incompatible. Although when a firm is healthy and obligations are being met, any tension arising from such potentially incompatible objectives will only be theoretical.

Conversely, as the boundary of financial distress is crossed, and the firm enters the ZOI, it is highly likely that the incompatible objectives will result in real tension between funders and management. It has also been argued that once the firm crosses the boundary of financial distress, the claim on residual value of the firm transfers from shareholders to creditors because shareholders have, by that stage, effectively lost their investment (Tung 2006). In this case, one can argue that an explicit agency relationship between creditors as the principal and management as the agent is created. In cases where management holds a high fraction of equity, the tension that arises as a result of incompatible objectives is likely to be exacerbated. It has also been argued by Tung (2006) that 'post-insolvency investments by the firm are a gamble with creditor's money' (p. 612). ${ }^{1}$ Thus, one can argue that management with a high fraction of equity ownership will be faced with making choices to achieve the incompatible objectives of (1) personal utility maximisation and (2) meeting the obligations required by creditors.

1.Tung (2006) refers to 'post-insolvency' which is an imprecise definition, and the term 'zone of insolvency' is more illustrative of reality. Therefore, for the purposes of this
research it is argued that the chosen definition of 'financial distress' aligns with the 'posearch it is argued thalvency' term.
Kahneman and Tversky (1979) argue that when faced with the prospect of loss, which, for owner-managers, is the loss of personal utility, people are inclined to become risk seeking. Thus, when a firm crosses the financial distress boundary the managers may become risk seeking, while the providers of funding in the role of principal carry a disproportionate amount of the risk.

However, it may also be argued that once the boundary of financial distress is crossed, then an altered agency relationship exists between management and creditors. Creditors become the principal because they have priority claim in any residual value of the firm, and management are the agents because they have authority to act on behalf of the principal.

\section{Management cognition and stakeholders}

Panicker and Manimala (2015) assert that to improve the chances of turnaround success, management needs to recognise problems early on and then take immediate action. This argument is consistent with Gopinath's (1991) view that any turnaround hinges on management recognising and admitting that the firm is distressed. Other scholars have offered management bias (Abatecola, Farina \& Gordini 2011; Rockwell 2016), and fixed mental models of existing management (Combe \& Carrington 2015) as obstacles to management cognition of distress, resulting in inertia and organisational failure. Furthermore, in small and medium enterprises (SMEs) which are generally owner-managed, this inertia and resistance to strategic change have been recognised as the outcome of founding shareholders' commitment to a firm's original strategy (Brunninge, Nordqvist \& Wiklund 2007).

Similarly, recent research into stakeholder theory suggests that management of companies that have failed tends to the narrative of 'scapegoating', with negative performance attributed to external causes. Simultaneously, they mask shortcomings of the company, but are very ready to claim any small success that might come about (Smudde \& Courtright 2011). These findings also suggest that a lack of cognition is common among failed firms and are consistent with the views articulated by Panicker and Manimala (2015) and Gopinath (1991).

\section{Distress and top management teams - established theory}

A long-standing view exists that the top management teams (TMT) in place, while the financial distress developed, have such fixed views on the way the business should be run that they may be incapable of turning it around (Hofer 1980) and that a successful turnaround requires retaining only capable management (Burbank 2005). Leaders are often seen as a contributing source of decline with a concomitant loss of credibility, resulting in a further deterioration of a firm's internal climate with an increase in dysfunctional 
consequences (Arogyaswamy, Yasai-Ardekani \& Barker III 1995). Executives either directly caused the problems at the heart of crisis or failed to recognise the problems early enough. Therefore, it may be argued that in financially distressed businesses that are privately owned it is possible that the lack of cognition by management and the self-interest of shareholders in management positions are likely to limit the removal and replacement of top management, thereby reducing the possibility of a successful turnaround.

Existing evidence suggests that organisational inertia hinders TMT replacement, and it has been argued that boards of directors with greater independence are likely to be more decisive when considering replacement of top management (Trahms et al. 2013). For privately owned businesses, this may not be the case because of shareholders themselves filling key management roles. It is possible, therefore, to speculate that where a high fraction of equity is owned by management, low turnover of top management will occur even though the balance of evidence suggests that it is a key feature of successful turnarounds. Aside from the ability of existing top management, it is also likely that information presented by them will selectively support their own selfinterest. This contention is supported by research that argues that the proportion of independent directors on boards is positively associated with the comprehensiveness of financial disclosures (Chen \& Jaggi 2000).

\section{Distress and information}

Asymmetry of information is an established view (Chancharat \& Chancharat 2013; Clarke 2007; Eisenhardt 1989; Taljaard 2013; Tung 2006), and 'managers' financial reporting and disclosure choices are associated with contracting, political cost, and capital market considerations' (Healy \& Palepu 2001:431). It is possible, therefore, to argue that the full extent of distress may become evident only when a formal (legal) business rescues or liquidation process is initiated.

\section{Boards of directors and the zone of insolvency}

A study (Dahya, Dimitrov \& McConnell 2008) analysed the relationship between corporate value and board composition in 22 countries, and found that performance was positively correlated with the fraction of independent directors on the board. It has also been shown by other researchers that various corporate governance characteristics of firms, financial distress and the survival chances of firms in distress can be correlated (Abatecola et al. 2011; Fich \& Slezak 2008; Jaikengkit 2004). Specifically, the number of independent directors is positively correlated with financial health, and solvent companies tend to have larger boards (Platt \& Platt 2012). The principal of independence, as a significant feature of good corporate governance, is reflected in two of the most credible and recognised corporate governance codes of best practice, namely: (1) The United Kingdom's Combined Code and (2) South Africa's King III. ${ }^{2}$

2.At the time of this research, the King ili code was the recognised code for South Africa with King IV in draft.
Although this research did not aim to deal with specifics of any corporate governance codes of practice, the purposive sample was drawn from the population of South African privately owned firms in financial distress. Thus, it is worth noting that a cornerstone of the King III code for South Africa is that a board should be composed predominantly of independent directors and that the chief executive officer (CEO) and chairperson of the Board should not be the same person. It is also worth noting that the King III code is a voluntary code of best practice, and although it is a mandatory requirement of the Johannesburg Stock Exchange for public companies to comply, there is nothing compelling a privately owned company to adopt the code. These features of King III are consistent with the view that independent oversight is a suitable mechanism for ensuring that the actions of those with authority are aligned with the interests of owners, and have been described as monitoring activities in agency theory literature.

Agency theory identifies monitoring activities as one of the drivers of agency costs. It can thus be argued that this is a prime responsibility of the board, and as a distressed firm's governance characteristics affect its possibility of bankruptcy (Fich \& Slezak 2008), monitoring activities are key in avoiding financial distress. It has also been argued that smaller boards with a higher proportion of outside directors along with larger ownership stakes by inside directors are more successful in avoiding bankruptcy once distress is identified (Fich \& Slezak 2008). This is consistent with the view that greater board independence and diversity among directors support the prevention of distress (Abatecola et al. 2011; Fich \& Slezak 2008; Jaikengkit 2004) and that a larger, more functionally diverse group can increase creativity (Brunninge et al. 2007:298). This could balance the dominant influence of management with concentrated equity holdings.

The work of Jaikengit (2004) on Thai financial institutions reveals two interesting factors of corporate governance as $e x$ ante early warning prediction of financial distress. These two factors are: (1) board independence and (2) ownership structure, as shown in Figure 2.

Jaikengit's (2004) findings lend support to an argument that for privately owned firms in the ZOI a number of characteristics exist, namely, high concentration of equity holders in management positions may result in delayed cognition of financial distress with delayed action to alleviate the distressed position. It also follows that contrary to what corporate governance theory suggests, for privately owned firms in the ZOI, agency cost represented by board size, board independence is unlikely to bring about early management cognition of distress and preserve firm value. Furthermore, the likelihood of a smaller board, limited board independence and increased likelihood of CEO duality will limit the influence that the board has on risky decisions of management; thus, the board composition of private firms in distress is unlikely to act as early stimulus for management 


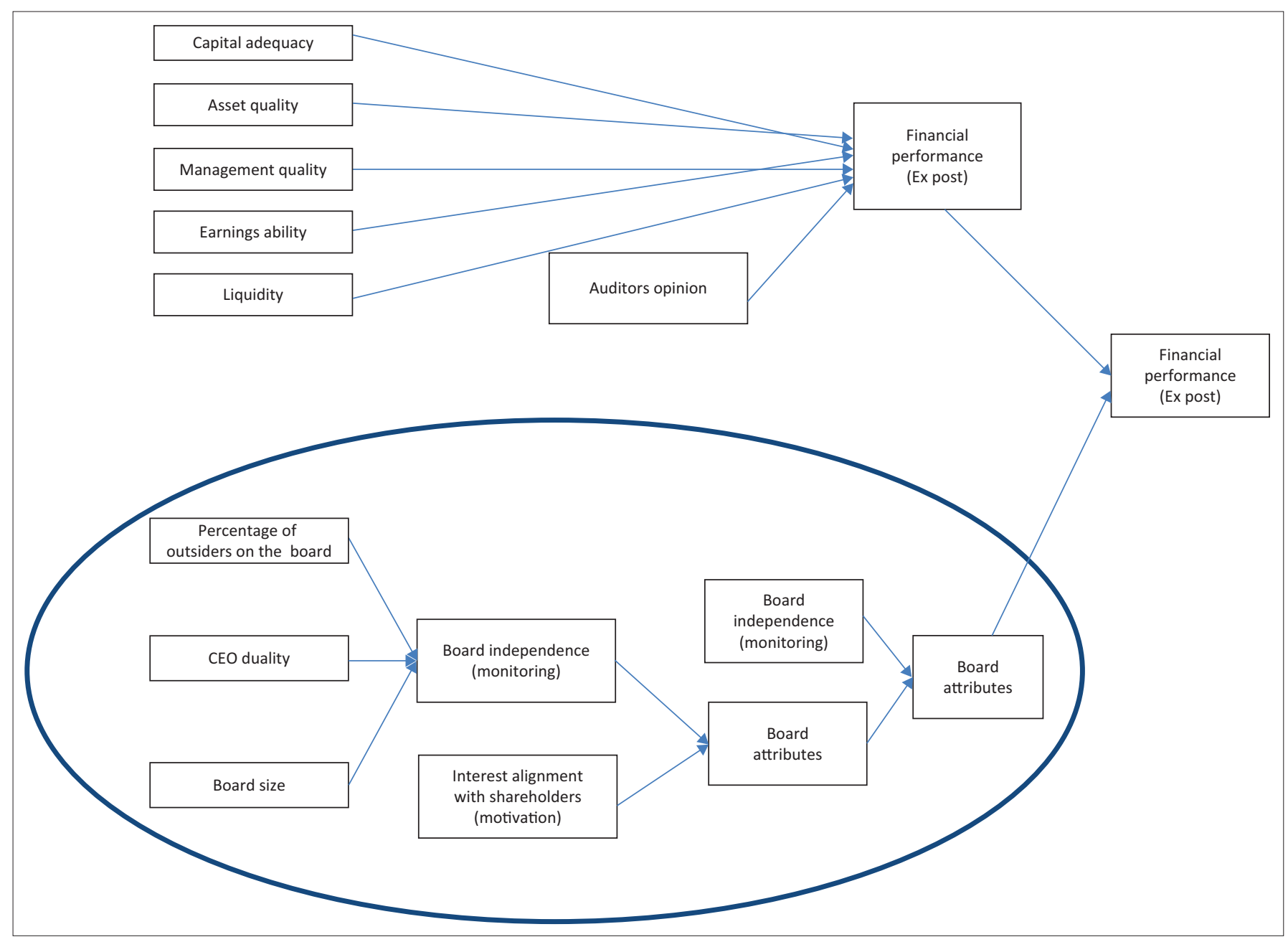

Source: Adapted from Jaikengit 2004

FIGURE 2: Early warning indicators and financial distress.

cognition of distress which, furthermore, is unlikely to limit the cost of cognition delay.

These characteristics can be represented in the conceptual model and hypotheses, as shown in Figure 3.

Figure 3 shows the main hypotheses of this research, namely:

H1: In the ZOI, a correlation exists between the fraction of equity owned by management and the turnaround boundary value of the firm.

H2: This set of hypotheses deals with the relationship between the individual variables collectively referred to as board composition and the variable turnaround boundary value of the firm

$\mathrm{H}_{\mathrm{A}}$ : A positive correlation exists between total number of directors on the board and the turnaround boundary value of the firm.

$\mathrm{H}_{\mathrm{B}}$ : A positive correlation exists between total number of independent directors on the board and the turnaround boundary value of the firm.

$\mathrm{H}_{\mathrm{C}}$ : A negative correlation exists between CEO duality and the turnaround boundary value of the firm. In other words, when a firm is in the ZOI, the greater the occurrence of CEO duality, the lower the turnaround boundary value of the firm.

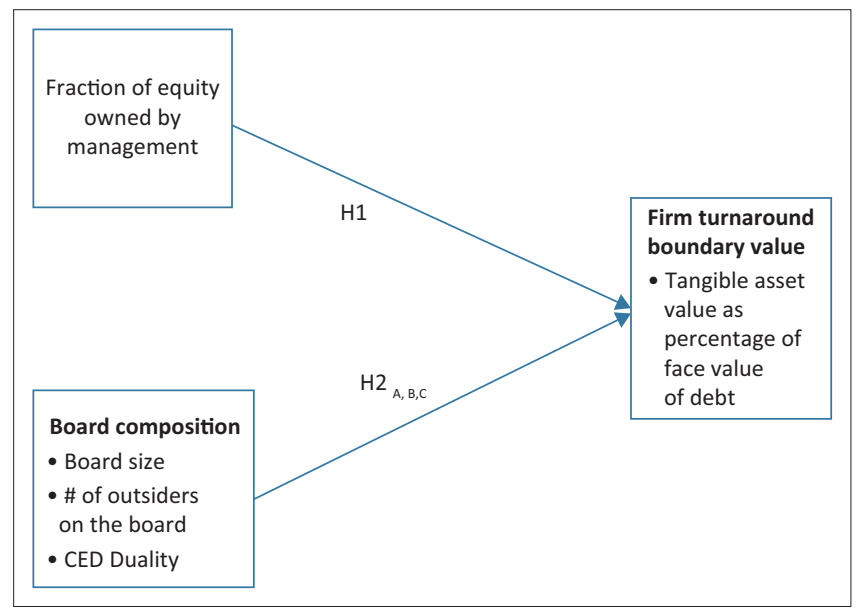

FIGURE 3: Conceptual research model.

\section{Research methodology}

In keeping with previous research in this field (Altman 1968; Clarke \& Buchanan 2010; Jaikengkit 2004; Kiel \& Nicholson 2003; Parker, Peters \& Turetsky 2002; Smith \& Graves 2005; Taffler 1984; Trahms et al. 2013), a quantitative research approach that is consistent with an objective position was utilised. This approach allowed for the measurement of 
TABLE 1: Make-up of sample studied.

\begin{tabular}{llc}
\hline Number & Description & Quantity $(N)$ \\
\hline 1 & Total cases reviewed & 127 \\
2 & Cases with incomplete or incomprehensible financial data & 17 \\
3 & Cases with public company shareholders & 6 \\
4 & Net number of cases $(n)$ included in analysis & 104 \\
\hline
\end{tabular}

strength of relationship between the variable described as the turnaround boundary value of the firm and the variables: (H1) the fraction of equity owned by management and (H2) the variables described collectively as board composition.

\section{Sample}

The sample, shown in Table 1, consisted of data gathered for 127 cases of companies that had commenced with business rescue proceedings. The data were sourced from official business rescue documents, company records, business rescue plans, minutes of creditors' meetings and legal affidavits.

For companies in business rescue the relevant financial reports are available in at least two places: (1) as part of the background presented at the first meeting of creditors and distributed to affected parties in advance of the meeting or as part of the minutes of the meeting, and (2) as part of the financial information contained in any published business rescue plan (Pretorius \& Rosslyn-Smith 2014) as required in Chapter 6, Section 150 (1) (a) of the South African Companies Act.

As there is no comprehensive database of business rescue information to which a researcher can turn, to draw a sample using strict random sampling techniques would not have been successful. However, it was possible to achieve a purposive sample by approaching various commercial entities who are exposed to, and engage regularly with distressed businesses, and are included as an affected party as defined in Chapter 6 of the new Companies Act. These include, but are not limited to, the following: providers of credit insurance: (1) Credit Guarantee, ${ }^{3}$ (2) Marsh ${ }^{4}$ and (3) Lombard. ${ }^{5}$ Providers of finance, which, in this case, are the large banks operating in South Africa. Academics doing research in this field who were willing to participate, with CIPC as the regulatory authority, as well as the Turnaround Management Association members and business rescue practitioners.

These entities were approached and were requested to share randomly selected copies of business rescue plans on a confidential basis.

The first step in extracting the data was to interrogate the contents of each case to ensure that the data in respect of each of the variables in the research model could be extracted. Each case was also interrogated to ensure that only privately owned companies were included in the final sample.

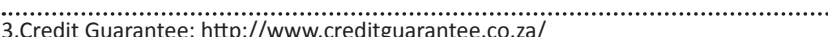
4.Marsh: http://africa.marsh.com/CountrySites/SouthAfrica/Home.aspx 5.Lombards: http://www.lombardins.com/products/short-term-insurance/trade-credit
TABLE 2: Descriptive statistics of the sample firms $(N=103)$.

\begin{tabular}{lccc}
\hline Descriptive statistics & Mean & SD & $\boldsymbol{N}$ \\
\hline Size - turnover ZAR & 16.0197 & 1.64216 & 104 \\
Management shares & 0.9381 & 0.19492 & 104 \\
Total directors & 1.9111 & 1.19955 & 104 \\
Independent directors & 0.0198 & 0.19609 & 104 \\
Board duality coded & 1.0192 & 0.13800 & 104 \\
Tangible assets total liabilities & 0.6411 & 0.40800 & 103 \\
\hline
\end{tabular}

SD, standard deviation; ZAR, South African rand.

Note: It was found that one case showed up as an outlier for the measure of the turnaround boundary (tangible assets total liabilities) with a mean or $>4.1$. Hence, on that variable $N=103$.

No attempt was made to classify the cases by industry. However, at least 28 different types of businesses were identified, including but not limited to, retail, wholesale, manufacturing, services, automotive, transport, mining, restaurant, warehousing and transport.

The empirical findings are presented next in the form of descriptive statistics and test of association for each hypothesis. This is followed by a discussion of the findings.

\section{Findings}

The descriptive statistics in Table 2 are for the variables depicted in the conceptual research model (Figure 3). The demographics for the sample analysed are presented thereafter.

It has been argued that where management owns a significant portion of equity in a firm, they may see the firm as existing for their own utility maximisation exclusively. Such management may thus frame decisions such that these decisions are not aligned with the best interests of the firm (Wiseman \& Gomez-Mejia 1998). In addition, when faced with the prospect of loss they may become risk seeking (Kahneman \& Tversky 1979; Tversky \& Kahneman 1981). For these reasons, the fraction of equity owned by management has been included as a variable in the conceptual research model. The mean fraction of equity owned by management in the sample was 0.9381, with $S=0.194$ (Table 2).

Board size has been shown in previous research to correlate with the incidence of distress (Jaikengkit 2004). Board diversity has also been shown to be associated with the prevention of distress (Abatecola et al. 2011; Fich \& Slezak 2008; Jaikengkit 2004), and it is logical that board diversity can only occur if there is more than one director on the board. Therefore, the measure of total number of directors has been included as a variable in this research. The mean of total directors in the sample was 1.91, with a standard deviation of $S=1.2$ (Table 2).

Previous research has identified board independence as playing a significant role in the avoidance of financial distress (Abatecola et al. 2011; Fich \& Slezak 2008; Jaikengkit 2004) and in the incidence of successful turnarounds (Trahms et al. 2013). The mean number of independent directors in the sample was 0.0198 , with a standard deviation of $S=0.196$ (Table 2).

The most widely accepted corporate governance codes of best practice support the view that independence and 
diversity of a board is enhanced by the appointment of an independent non-executive chairperson. The existence of CEO duality was also identified by Jaikengkit (2004) as a significant feature of financial distress.

Chief executive officer duality is a dichotomous categorical variable where the existence of CEO duality was coded as a 1 and where the CEO and chairperson roles were held by separate people was coded as a 2. Chief executive officer duality existed in 102 cases (98.1\%) and there were only two cases $(1.9 \%)$ where it did not exist. The result is shown in Table 3, and to illustrate the point that the existence of CEO duality is a predominant feature of the sample of private firms in the ZOI.

The variables 'current assets' and 'current liabilities' for the sample allowed consideration of the aggregate liquidity position of the sample, as shown in Figure 4.

Figure 4 shows a total of R2.6 billion for the sample's aggregated current liabilities against a total of R1.1bn for the sample's aggregated current assets with a resultant liquidity shortfall of R1.5bn for the sample. It is obvious that, at an aggregate level, the firms in the sample used for this research would be unable to meet their short-term debt requirements

Figure 5 shows that, for the sample studied, the sum of total liabilities for all 104 cases was R4.8bn and the sum of tangible assets was $\mathrm{R} 2.8 \mathrm{bn}$. The resulting shortfall of tangible assets to cover total liabilities was R2.0bn. Thus, at an aggregate level, the firms contained in the sample used for this research may be considered to be functionally insolvent.

Size was included as a control variable and was shown to be significant at the $p<0.01$ level with a small correlation of $r=0.261$ to the turnaround boundary value variable.

TABLE 3: Frequency of evidence of chief executive officer duality.

\begin{tabular}{lcc}
\hline Finding & Frequency $(\boldsymbol{n})$ & $\mathbf{\%}$ \\
\hline CEO duality was present & 102 & 98.1 \\
CEO duality was not present & 2 & 1.9 \\
\hline Total & $\mathbf{1 0 4}$ & $\mathbf{1 0 0 . 0}$ \\
\hline
\end{tabular}

CEO, chief executive officer.

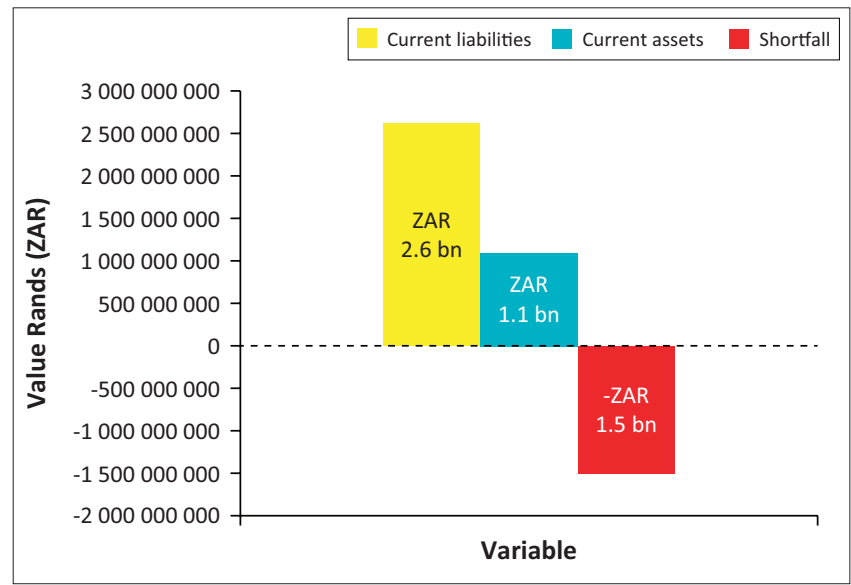

FIGURE 4: Aggregate liquidity position of all sample cases.

\section{Hypothesis 1}

A Pearson's product-moment correlation was run to assess the relationship between the fraction of shareholding owned by management and the turnaround boundary value of the firm. The result was a small correlation of $r=0.081$ that was not significant, meaning that the null hypothesis, in the ZOI no correlation exists between the fraction of equity owned by management and the turnaround boundary value of the firm, could not be rejected

\section{Hypothesis 2}

This set of hypotheses deals with the relationship between the individual variables collectively referred to as board composition and the variable turnaround boundary value of the firm (see also Figure 3).

The Pearson's product-moment correlation assessed the relationship between the board composition (total number of directors, number of independent directors) and the turnaround boundary value of the firm. A Point-Biserial correlation was run between CEO duality and the turnaround boundary value of the firm. The results for each hypothesis are reported below.

\section{Hypothesis $\mathbf{2}_{\mathrm{A}}$}

A positive correlation exists between total number of directors on the board and the turnaround boundary value of the firm.

Results indicate a small, negative correlation that is not significant between total number of directors on the board and the turnaround boundary value of the firm, $r=-0.117, p>$ 0.05. Thus, the null hypothesis, that in the ZOI, no relationship exists between the total number of directors and the turnaround boundary value of the firm, cannot be rejected.

\section{Hypothesis $\mathbf{2}_{\mathrm{B}}$}

A positive correlation exists between total number of independent directors on the board and the turnaround boundary value of the firm.

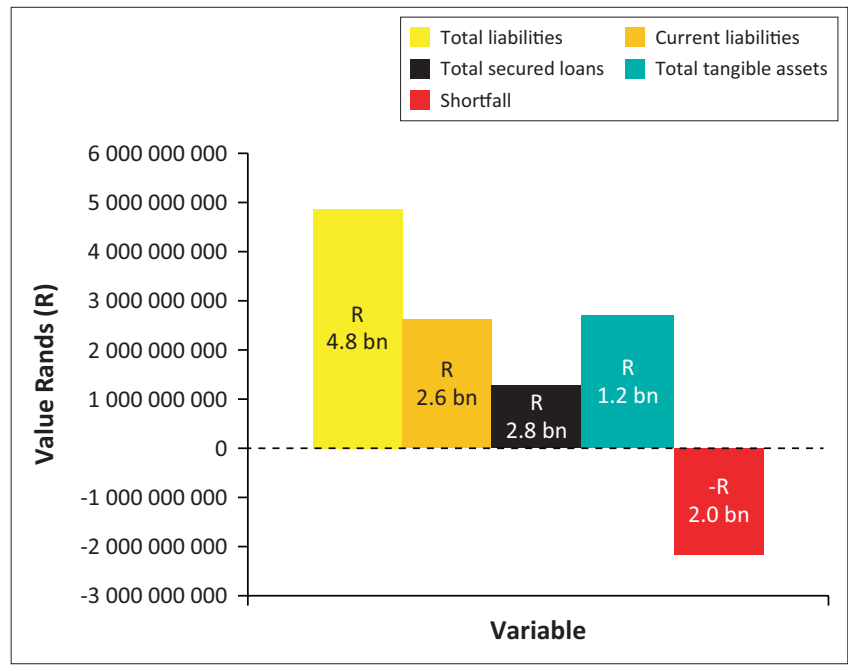

FIGURE 5: Key solvency metrics for the aggregate sample. 
Results indicate a very small, positive correlation that is not statistically significant between total number of independent directors on the board and the turnaround boundary value of the firm, $r=0.014, p>0.05$. Thus, the null hypothesis, that in the ZOI, no relationship exists between the total number of directors and the turnaround boundary value of the firm, could not be rejected.

\section{Hypothesis $2_{c}$}

A negative correlation exists between CEO duality and the turnaround boundary value of the firm. In other words, when a firm is in the ZOI, the greater the occurrence of CEO duality, the lower the turnaround boundary value of the firm.

A Point-Biserial correlation showed the relationship between CEO duality and the turnaround boundary value of the firm.

There was a small probability of correlation between CEO duality and the turnaround boundary value of the firm. It was statistically not significant $r_{\mathrm{pb}}(104)=0.014$. One cannot, therefore, reject the null hypothesis, stating that no relationship exists between CEO duality and the turnaround boundary value of the firm.

\section{Discussion}

This paper opened by noting the observation of Gopinath (1991), who maintained that the first step in arresting decline and preventing failure was for management to recognise and admit that there was a problem. The crosssectional research done in this study was founded on the premise that the formal filing for legal protection under a business rescue regime is evidence that recognition of a problem within a firm had taken place. Furthermore, it is evidence that management had admitted there was a problem. It is also a signal that at least some stakeholders believe that a turnaround may be possible. Thus, the filing for formal and legally protected turnaround serves to mark a boundary between decline and possible turnaround.

This boundary may not be the same as the boundary between financial wellness and financial distress. So, in reality, a firm that has entered the 'zone of insolvency' will have crossed this first boundary ('distress'), albeit an imprecisely defined boundary (Barondes et al. 2007), before it reaches the boundary between 'decline' and possible 'turnaround'.

Thus, it may be argued that even though the zone between the two boundaries falls within the ZOI it is also somewhat of a 'no-man's land'. It is an observation of the researcher that this 'no-man's land' may be characterised by low visibility, apparently risky decisions and inadequate oversight. Indicative of this observation is the fact that $13 \%$ (17 of the initial cases) had to be excluded from analysis in this research because of incomplete or incomprehensible financial data.

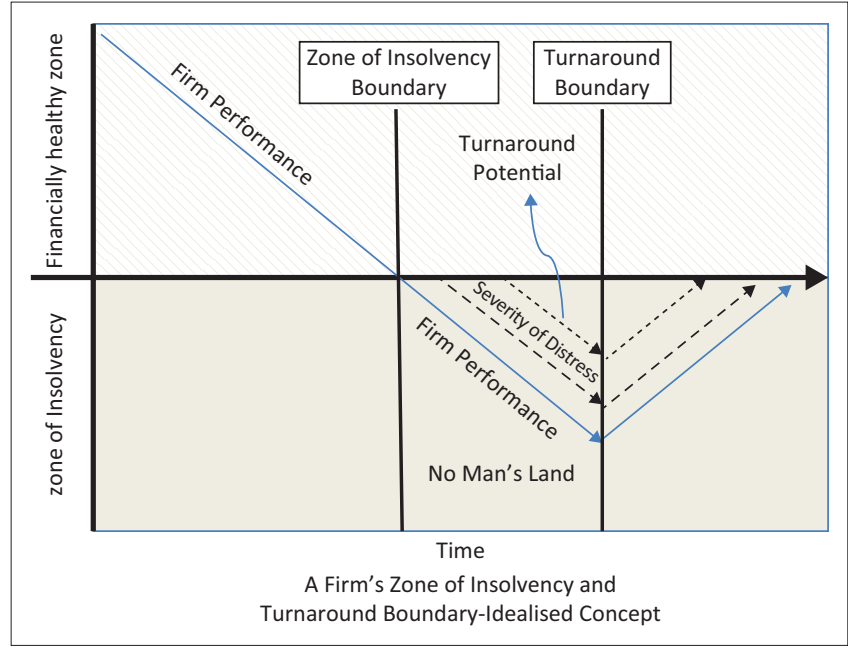

FIGURE 6: Idealised concept of the zone of insolvency boundary and turnaround boundary.

The notion of two boundaries (ZOI and turnaround) is shown as an idealised ${ }^{6}$ concept in Figure 6. Delay in cognition by management, as argued by Panicker and Manimala (2015), is likely to see a firm's distress worsening and the turnaround potential eroded. This inertia and resistance to change, as identified by Brunninge et al. (2007), is likely to result in cognition of distress (the first step required for a turnaround) only occurring at some time after the onset of financial distress. Hence, the argument that for firms in financial distress and attempting a turnaround, there are likely to be two boundaries that exist within the ZOI, namely, (1) the ZOI boundary and (2) the turnaround boundary, which occur at some time after the onset of distress and once management has recognised and accepted the distressed position.

Given that the success of business rescue is shown by prior research to be less than $10 \%$ (Pretorius 2015), it follows that many firms that enter the ZOI will not follow the idealised improvement beyond the turnaround boundary, as shown in Figure 6.

The mean value of tangible assets as a ratio of face value of debt for the sample in this research is 0.6411 (Table 2). In other words only $64.1 \%$ of the face value of debt (liabilities) is covered by the total tangible asset value. It may be argued that the ZOI may commence when the value of a firm's tangible assets is R1.00 lower than the face value of debt. This view is aligned with the solvency test which is simply carried out by assessing whether a firm's assets are greater or less than a firm's liabilities. Using this assessment the firms in this research are significantly beyond the insolvency threshold. Both the aggregate liquidity (Figure 3) and solvency (Figure 4) results for firms in this sample also support this conclusion and the contention that the firms' turnaround boundary value is significantly lower than the firms' likely value at the commencment of the ZOI. In this research, the tangible asset value versus face value of debt

6.The notion of an "idealised concept" is borrowed from scientific (physics) research only by creating fictitious, ideal entities and then descending from them by means only by creating fictitious, ideal entities and then descending from them by means
of experiment and approximation to the 'roughness of experience' is it possible to combine mathematics and reality (Coniglione 2004). 
TABLE 4: Correlations between elements of board composition and turnaround boundary value.

\begin{tabular}{|c|c|c|c|c|c|c|c|c|}
\hline Variable & Statistical test & Size & $\begin{array}{l}\text { External } \\
\text { fund }\end{array}$ & $\begin{array}{l}\text { Management } \\
\text { shares }\end{array}$ & $\begin{array}{c}\text { Total } \\
\text { directors }\end{array}$ & $\begin{array}{l}\text { Independent } \\
\text { directors }\end{array}$ & $\begin{array}{c}\text { Board } \\
\text { duality }\end{array}$ & $\begin{array}{l}\text { Turnaround boundary value } \\
\text { (tangible assets/total liabilities) }\end{array}$ \\
\hline Size & Pearson correlation & 1 & - & - & - & - & - & - \\
\hline $\begin{array}{l}\text { External funding as percentage of total } \\
\text { funding }\end{array}$ & Pearson correlation & -0.179 & 1 & - & - & - & - & - \\
\hline Management's per cent of shareholding & Pearson correlation & $-0.208^{*}$ & 0.188 & 1 & - & - & - & - \\
\hline Total directors & Pearson correlation & $0.300 * *$ & -0.140 & $-0.235^{*}$ & 1 & - & - & - \\
\hline Independent directors & Pearson correlation & 0.115 & 0.064 & 0.032 & $0.337 * *$ & 1 & - & - \\
\hline $\begin{array}{l}\text { Turnaround boundary value (tangible } \\
\text { assets/total liabilities) }\end{array}$ & Pearson correlation & $0.261 * *$ & -0.116 & 0.081 & -0.117 & 0.014 & -0.095 & 1 \\
\hline
\end{tabular}

*, Correlation is significant at the 0.05 level (two-tailed); $* *$, Correlation is significant at the 0.01 level (two-tailed).

assessment was done at that point in time when each firm in the sample was placed into business rescue and it may be argued that cognition by management had occurred. Thus, by extension it may be true to say that the turnaround boundary for the firms in this research was located where the mean value of tangible assets was only $64.1 \%$ of the face value of debt. Thus, if the ZOI boundary is where the value of tangible assets equals the face value of debt (total liabilities), then it is also true to say that at least a further $35.9 \%$ of the firms' net asset value was eroded before the turnaround boundary was reached.

Prior research shows that the main reasons firms file for business rescue are creditor pressure and profitability problems (Pretorius 2015). This supports the view of this research that management holds on desperately for far too long before taking decisive action, which results in a very weak solvency and liquidity position. Furthermore, it suggests that any firm responding to external pressure and seeking legal protection via a formal turnaround process is probably a result of management making a 'last gasp' attempt at a turnaround. The mean turnaround boundary value of the firms in this sample was 0.6411 (Table 2) which supports the view that management has held on for far too long before taking decisive turnaround action and may be viewed as crossing the turnaround boundary.

The $64.1 \%$ mean turnaround boundary value of the firms in this research is comparable to findings published by Davydenko (2012), who determined the average level of the 'value-based default boundary' was $66 \%$ of the face value of debt. The 'value-based default boundary' to which he refers is the market value of the firm's assets (Davydenko 2012). This also suggests that perhaps cognition and hence crossing the turnaround boundary may only happen as a result of impending default or as an attempt to stave off the consequences of default.

The value attached to tangible assets is likely to be overly optimistic, as a result of information asymmetry and biased reporting on the part of management (Smudde \& Courtright 2011). On the open market, the value is likely to be significantly lower than the reported value. So, the $64.1 \%$ coverage may be considered as conservative (generous). This further supports the argument that, on average, the sample firms in this research were already desperately insolvent before decisive action was taken. Informal personal discussions ${ }^{7}$ with business rescue practitioners, turnaround professionals and bankers revealed that the true market value of a distressed firm's assets may be as little as $10 \%$ or $20 \%$ of the value reported in the company's records.

These large shortfall statistics suggest that incumbent management simply held on for far too long. A potential explanation for this could be (1) lack of management cognition of the problem, which is consistent with the views of Smudde and Courtright (2011) or (2) cognition had taken place but the fact that management owns $93.8 \%$ of the equity leads them to become risk seeking when faced with the prospect of loss as described by Kahneman and Tversky (1979) and Fich and Slezak (2008).

The first reason (cognition) may be as a result of fixed mental models (Combe \& Carrington 2015) or management bias (Abatecola et al. 2011; Rockwell 2016). This may further support the contention that existence of management inertia is a noteworthy contributor to organisational failure.

As for management becoming risk seeking, it appears impossible for a definitive conclusion to be formed in respect of specific cases. However, based on the evidence, it seems that, at the aggregate level, firms are desperately insolvent and support the view that once a firm is in the ZOI but has not commenced a formal turnaround process, the risk resulting from management decisions is carried by creditors.

\section{Conclusion}

The mean turnaround boundary value of the firms in this sample at $64.1 \%$ is very close to the average level of the 'value-based default boundary' of $66 \%$ of the face value of debt as identified by Davydenko (2012).

It can be speculated that this may be because the owners of firms, managed by a controlling owner(s), value the firm as equal to the personal utility that the firm provides them (Schulze et al. 2003). It follows, therefore, that controlling owners may not manage the firm in the firm's own best interest but in their own personal interest which may result in a degree of anxiety on the owners' part, particularly when 7.To respect confidentiality, the names and organisations of the individuals with whom the researcher had personal discussions are excluded from the reference list. 
they have provided some form of personal security as is often expected (White 2016).

It may be argued that such management is more oriented towards protecting their personal utility position than serving the interests of the company. Therefore, for private firms that cross the boundary of distress and enter the ZOI, it would be advisable for creditors, particularly those that are unsecured, to take swift and bold action.

The sample firms studied in this research had a mean of $93.8 \%$ of the firm's equity owned by management. This indicates that for private firms within the ZOI there is unlikely to be a separation of ownership and authority, which is the predominant underlying requirement for most corporate governance theory. The lack of correlation between external funding and board composition also suggests that funders do not place much reliance on board size and independence as credit risk mitigation mechanisms.

\section{Limitations and further research}

Three possible limitations have been identified for this research. They are sample definition, geography and the possibility of information asymmetry.

It is possible for management to recognise the existence of financial distress and to effect a turnaround without the company having entered formal and legally protected business rescue. Companies having these characteristics between the period of 1 May 2011 and 30 June 2016 will have been omitted from the sample drawn in this research.

South Africa was selected as a research setting because the country boasts a regulatory and institutional framework that supports the enforcement of good corporate governance and South Africa instituted a new Companies Act on 1 May 2011 (Companies Act 71 of 2008 2011) (RSA 2008) which includes provision for the rehabilitation of financially distressed companies. It is fair to argue that other geographic regions in the world may have equally compelling factors that influence behaviour of private firms in financial distress. Thus, generalisation of this research's findings to other geographies and economies should be done with this in mind.

This article argued that asymmetry of information relating to any individual firm exists. Furthermore, 17 individual cases (13\% of the total sample) drawn in the original sample for this research were rejected for analysis on the grounds of incomplete or incomprehensible information. Consequently, it is possible that information in respect of other private firms may be biased or otherwise inaccurate.

\section{Further research}

The mean turnaround boundary value of the firms in this sample (0.6411) considers only total liabilities, which may obscure: (1) the different outcomes that could be experienced by secured and unsecured creditors and (2) the weighting that shareholder loans has on management decision-making.

The security that any creditor has is likely to influence their actions and any shortfall of total tangible assets over total liabilities, which in this research sample is likely to be a minimum of $35.9 \%$, will be carried in predominance by the unsecured creditors. Hence, an understanding of the likely differences for secured and unsecured creditors would be valuable. Similarly, the personal risk of loss that shareholders face through their shareholders' loans and the possibility that shareholders may have provided personal surety to creditors could see the decision-making dynamics shift in favour of personal interests and away from what may be in the interest of the firm.

\section{Acknowledgements Competing interests}

The authors declare that they have no financial or personal relationships that may have inappropriately influenced them in writing this article.

\section{Authors' contributions}

K.J.F. completed this research as part of a PhD thesis and M.P. was his supervisor for the PhD research thesis.

\section{References}

Abatecola, G., Farina, V. \& Gordini, N., 2011, 'Empirical research on corporate distress: Assessing the role of the boards of directors', in XX Tor Vergata conference on money, banking and finance: 'Actors, rules and policies after the global financial crisis' held at Tor Vergata University, Rome, December 5-7, 2011, pp. 1-36.

Allen, P., 1992, 'Credit Lyonnais Bank Nederland, N.V Vs Pathe Communications Corporation', The Delaware Journal of Corporate Law 17(3), 1099-1159.

Altman, E., 1968, 'Financial ratios, discriminant analysis and the prediction of corporate bankruptcy', The Journal of Finance XXIII, 589-609.

Ang, J.S., Cole, R.A. \& Lin, J.A.W., 2000, 'Agency costs and ownership structure', Journal of Finance 55(1), 81-106. https://doi.org/10.1111/0022-1082.00201

Arogyaswamy, K., Yasai-Ardekani, M. \& Barker III, V.L., 1995, 'Firm turnarounds: An integrative two-stage model', Journal of Management Studies 32(July), 493-525. https://doi.org/10.1111/j.1467-6486.1995.tb00786.x

Ayotte, K., Hotchkiss, E.S. \& Thorburn, K., 2013, 'Governance in financial distress and bankruptcy', in The Oxford handbook of corporate governance, pp. 489-514.

Barondes, R., Fairfax, L., Hamermesh, L.A. \& Lawless, R., 2007, 'Twilight in the Zone of insolvency: Fiduciary duty and creditors of troubled companies-History \& background', Journal of Business and Technology Law 1(2), 229-255.

Brunninge, O., Nordqvist, M. \& Wiklund, J., 2007, 'Corporate Governance and Strategic Change in SMEs: The effects of ownership, board composition and top management teams', Small Business Economics 29(3), 295-308. https://doi. org/10.1007/s11187-006-9021-2

Burbank, R.K., 2005, 'The classic five-step turnaround process', The Journal of Private Equity 8, 53-58. https://doi.org/10.3905/jpe.2005.490419

Cadbury, 2000, 'The corporate governance agenda', Corporate Governance: An International Review 8(1), 7-15. https://doi.org/10.1111/1467-8683.00175

Chancharat, S. \& Chancharat, N., 2013, 'Corporate Governance and Company Survival', Silpakorn University Journal of Social Sciences, Humanities, and Arts 13(1), 33-62.

Chen, C.J.P. \& Jaggi, B., 2000, 'Association between independent non-executive directors, family control and financial disclosures in Hong Kong', Journal of Accounting and Public Policy 19, 285-310. https://doi.org/10.1016/S02784254(00)00015-6

Clarke, D., 2007, 'Three concepts of the independent director', Delaware Journal of Corporate Law 32(1), 73-111.

Clarke, R. \& Buchanan, B., 2010, 'Turnaround strategies', Trustee: The Journal for Hospital Governing Boards 63(6), 26-28, 30-31, 1.

Combe, I.A. \& Carrington, D.J., 2015, 'Leaders' sensemaking under crises: Emerging cognitive consensus over time within management teams', Leadership Quarterly 26(3), 307-322. https://doi.org/10.1016/j.leaqua.2015.02.002

Coniglione, F., 2004, 'Between abstraction and idealization: Scientific practice and philosophical awareness', 82(Angelelli), 59-110. 
Dahya, J., Dimitrov, O. \& McConnell, J.J., 2008, 'Dominant shareholders, corporate boards, and corporate value: A cross-country analysis', Journal of Financial boards, and corporate value: A cross-country analysis', Journal of
Economics 87(1), 73-100. https://doi.org/10.1016/j.jfineco.2006.10.005

Davydenko, S.A., 2012, 'When do firms default ? A study of the default boundary', in EFA Moscow Meetings Paper; AFA San Francisco Meetings Paper; WFA Keystone Meetings, viewed n.d. from https://ssrn.com/abstract=672343 or https://doi. org/10.2139/ssrn.672343.

Djerbi, C. \& Anis, J., 2015, 'Boards, retained ownership and failure risk of French IPO firms', Corporate Governance: The International Journal of Business in Society 15(1), 108-121. https://doi.org/10.1108/CG-10-2013-0115

Eisenhardt, 1989, 'Agency theory: An assessment and review', Academy of Management Review 14(1), 57-74. https://doi.org/10.5465/amr.1989.4279003

Elloumi, F. \& Gueyié, J.-P., 2001, 'Financial distress and corporate governance: An empirical analysis', Corporate Governance 1, 15-23. https://doi.org/10.1108/ 14720700110389548

Fich, E.M.E. \& Slezak, S.S.L., 2008, 'Can corporate governance save distressed firms from bankruptcy? An empirical analysis', Review of Quantitative Finance and Accounting 30, 225-251. https://doi.org/10.1007/s11156-007-0048-5

Gopinath, C., 1991, 'Turnaround: Recognizing decline and initiating intervention', Long Range Planning 24(6), 96-101. https://doi.org/10.1016/0024-6301(91) 90048-S

Healy, P.M. \& Palepu, K.G., 2001, 'Information asymmetry, corporate disclosure, and the capital markets: A review of the empirical disclosure literature', Journal of Accounting and Economics 31, 405-440. https://doi.org/10.1016/S0165-4101(01) 00018-0

Hofer, C.W., 1980, 'Turnaround strategies', Journal of Business Research 1(1), 19-31.

Jaikengkit, A., 2004, 'Corporate governance and financial distress: An empirical analysis. The case of Thai financial institutions', in T. Fogarty (ed.), ProQues dissertations and theses, n.p., Case Western Reserve University, Cleveland, $\mathrm{OH}$.

Jensen, M.C. \& Meckling, W., 1976, 'Theory of the firm: Managerial behaviour, agency costs and ownership structure', Journal of Financial Economics 3, 305-360. https://doi.org/10.1016/0304-405x(76)90026-x

Kahneman, D. \& Tversky, A., 1979, 'Prospect theory: An analysis of decision under risk', Econometrica 47(2), 263-292. https://doi.org/10.2307/1914185

Kiel, G.C. \& Nicholson, G.J., 2003, 'Board composition and corporate performance: How the Australian experience informs contrasting theories of corporate governance', Corporate Governance: An International Review 11(3), 189-205. governance, Corporate Governance: An Inter
https://doi.org/10.1111/1467-8683.00318

Manzaneque, M., Priego, A.M. \& Merino, E., 2015, 'Corporate governance effect on financial distress likelihood: Evidence from Spain', Revista de Contabilidad, 19(1), 111-121.

Morck, R., Shleifer, A. \& Vishny, R.W., 1988, 'Management ownership and market valuation', Journal of Financial Economics 20, 293-315. https://doi.org/10.1016/ 0304-405X(88)90048-7

Panicker, S. \& Manimala, M., 2015, 'Successful turnarounds: The role of appropriate entrepreneurial strategies', Journal of Strategy and Management 8(1), 21-40.

Parker, S., Peters, G.F. \& Turetsky, H.F., 2002, 'Corporate governance and corporate failure: A survival analysis', Corporate Governance 2, 4-12. https://doi.org/ 10.1108/14720700210430298
Platt, H. \& Platt, M., 2012, 'Corporate board attributes and bankruptcy', Journal of Business Research 65(8), 1139-1143. https://doi.org/10.1016/j.jbusres.2011. 08.003

Polley, W.J., 2015, 'The rhetoric of opportunity cost', The American Economist 60(1), 9-19. https://doi.org/10.1177/056943451506000102

Pretorius, M., 2015, Business Rescue Status Quo Report: Final report (2015), Business Enterprises at University of Pretoria (Pty) Ltd., Pretoria.

Pretorius, M. \& Rosslyn, W., 2014, 'Expectations of a business rescue plan: international directives for Chapter 6 implementation', African Business Review 18, 2014.

Rajak, H., 2008, 'Director and officer liability in the zone of insolvency; A comparative analysis', Potchefstroom Electronic Law Journal/Potchefstroomse Elektroniese Regsblad 11(1), 31-66.

Rockwell, S., 2016, 'Identity processes to trigger turnaround in response to organizational decline', International Journal of Business and Management 11(3), 11. https://doi.org/10.5539/ijbm.v11n3p11

RSA (Republic of South Africa), (2008), 2011, Companies Act, Act No. 71 of 2008, with effect from 01 May 2011., Government Gazette No. 32121 (Notice No. 421) Government Printer, Pretoria.

Schulze, W.S., Lubatkin, M.H. \& Dino, R.N., 2003, 'Exploring the agency consequences of ownership dispersion among the directors of private family firms', Academy of Management Journal 46(2), 179-194.

Smith, A., 1776, An inquiry into the nature and causes of the wealth of nations, vol. II, W Strahan and T Cadell, London.

Smith, M. \& Graves, C., 2005, 'Corporate turnaround and financial distress', Managerial Auditing Journal 20, 304-320. https://doi.org/10.1108/02686900 510585627

Smudde, P.M. \& Courtright, J.L., 2011, 'A holistic approach to stakeholder management: A rhetorical foundation', Public Relations Review 37(2), 137-144. https://doi. org/10.1016/j.pubrev.2011.01.008

Taffler, R.J., 1984, 'Empirical models for the monitoring of UK corporations', Journal of Banking \& Finance 8(2), 199-227. https://doi.org/10.1016/0378-4266(84)90004-9

Taljaard, C., 2013, 'The association between diversity within boards and company financial performance - A graphical time-series approach', Unpublished master's thesis, Gordon Institute of Business Science, Johannesburg.

Trahms, C.A., Ndofor, H.A. \& Sirmon, D.G., 2013, ‘Organizational decline and turnaround: A review and agenda for future research', Journal of Management 39(5), 1277-1307. https://doi.org/10.1177/0149206312471390

Tung, F., 2006, 'Gap filling in the zone of insolvency', Journal of Business \& Technology Law 1(2), 607-631. https://doi.org/10.2139/ssrn.897792

Tversky, A. \& Kahneman, D., 1981, 'The framing of decisions and the psychology of choice', Science (New York, N.Y.) 211(4481), 453-458. https://doi.org/10.1126/ science. 7455683

White Michelle, 2016, 'Small Business Bankruptcy', Annual Review of Financial Economics 8, 1-30.

Wiseman, R.M. \& Gomez-Mejia, L.R., 1998, 'A behavioral agency model of management risk taking', Academy of Management Review 23(1), 133-153. https://doi.org/10.5465/amr.1998.192967 